\title{
Strategic Information Systems Planning Of Public Sector In Economic Crisis: An Integrated Framework
}

\author{
Georgios I. Farantos, PhD Candidate, M.P.A. \\ Nikitas Spiros Koutsoukis, Associate Prof. \\ Department of Political Science and International Relations, \\ University of the Peloponnese, Korinthos, Greece
}

\section{doi: 10.19044/esj.2016.v12n19p87 URL:http://dx.doi.org/10.19044/esj.2016.v12n19p87}

\begin{abstract}
The purpose of the study is to establish a framework for the impact of strategic planning on the public sector's information systems during the economic crisis. The survey has been designed for the literature review of the strategic planning of information systems and the enrichment through the review of the effect on this economic crisis. The research methodology extends to the literature review of strategic planning of information systems and the creation of a framework for its implementation in an economic crisis. We approach the general concepts of Strategic Management and Policy Analysis and also the more specific ones of Strategic Planning of Information Systems. We note the relationship between strategy and crisis and the relationship between efficiency and strategic management in the economic crisis. Based on the results of the survey for the strategic planning of public sector information systems, we enrich the study with more specific crisis management and we create a new study framework. Useful conclusions for the integrated management of public sector information systems in crisis arise. The study is limited by the introduction of the economic crisis and cannot be generalised as such in a period of normal operation of the organisations. This original research leaves room for further study cases in the future and completion of the strategic planning studies of public sector IT systems during the economic crisis.
\end{abstract}

Keywords: Strategic Management, Public Policy Analysis, Strategic Information Systems Planning, Management Information Systems, Economic Crisis, Efficiency variation

\section{Introduction}

The aim of the study is to establish a framework for the impact of strategic planning on the public sector's information systems during the 
economic crisis. The research methodology extends to the literature review of strategic planning of information systems and the creation of a framework for its implementation in an economic crisis.

Strategic Management [or Strategic Planning or Programming (S.P.)] is the total amount of decisions and actions on behalf of the Administration which define the long-term efficiency of an enterprise (Hunger and Wheelen, 2000). David (2009) equals strategic management to the term strategic planning, where the first term is used in business, and the second in academic fields (David, 2009). Bracker (1980) provides a definition regarding administrative strategic design stating that "strategic management means the analysis of an enterprise's external and internal environment in order to maximize the use of resources in relation to goals" (Bracker, 1980).

It includes detection of the environment (internal and external), the development of a strategy (strategic planning), strategy implementation, evaluation and control. Figure 1 shows the content of the Strategic Planning (based on Ansoff, 1996, Hunger and Wheelen, 2000). According to this approach, firstly, the group's common direction or group identity is defined. This gives the common elements that govern the group members and to which its members must adhere. Then comes the SWOT analysis (SWOT Analysis - Strength, Weakness, Opportunities, threats) which identifies the strengths and weaknesses as well as the opportunities and threats. The SWOT analysis begins with the External Environment Analysis, which examines the external environment of the enterprise and identifies the opportunities (including the opportunity to produce a new product for a competitive niche, or to develop a competitive advantage). The SWOT analysis also includes the Internal Environment Analysis which examines the interior of the organisation and identifies strengths and weaknesses. Upon completion of the SWOT analysis, a review of the group's joint direction is conducted. The next step in the Strategic Planning is Strategy formulation, which in each case can be defined as corporate, entrepreneurial and operational. The Strategy is also defined as the process of implementation of long-term goals. The Strategic Management Content, including all the elements of the Strategic Management process is shown on Figure 1. 


\section{Strategic Programming Content}

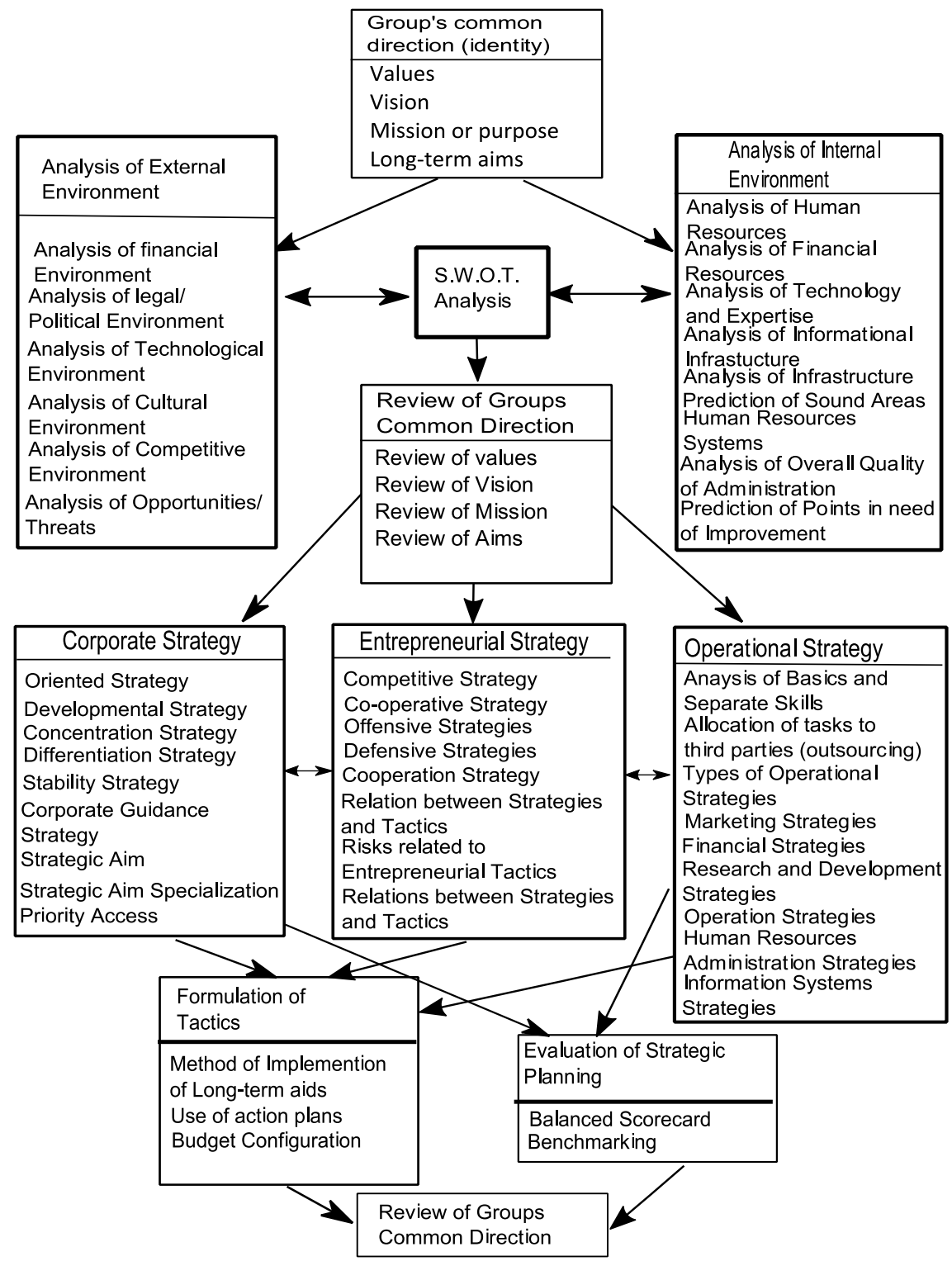

Fig. 1 : Strategic Management Content (based on Ansoff, 1996, Hunger and Wheelen, 2000)

The tactics formation follows, which is defined as the process of implementation of short-term goals using tactics programmes (action plan) and budget formulation. Evaluation is an important stage of Strategic Planning and can be implemented as an S.P evaluation with the Balanced Scorecard tool or as a Service evaluation with the Benchmarking tool. Then, the common direction or identity of the group is considered, as commonly referred to, which includes the vision, the mission, the goals and the 
objectives. The wording of the group's common direction is seen as a particularly important part of Strategic Management.

Strategic Planning is an Administrative Science method of management, initiated by the private sector and trying to be transplanted into the Public Sector. Policy Analysis regards mainly Public Policy, is a field of Political Science and is attempted to be applied in the Private Sector. Strategic Planning and Policy Analysis are applied to the modern environment and are often mentioned in the same administrative practices, in actions carried out or attempted to be carried out by government bodies, organisations and private enterprises. Wheelen, T. \& Hunger, D. (2012) studied the relationship between Strategic Management and Entrepreneurial Policy and noted the significance of Policy in the programming of the organisations’ actions.

\section{Strategic Management and Efficiency in Organisations during Economic Crises}

Strategic Management in Organisations, along with its adopted Strategies, plays an important role in the efficient operation of the Organisations in Economic Crisis conditions. The Economic Crisis requires reforms and changes in the operation of enterprises and Organisations in order to address the pathogens and failures that led to its emergence. In this context, the implementation of Strategic Management benefits Organisations that are in a crisis environment, increasing their efficiency and thus leading to their survival in the midst of the Crisis.

The implementation of a successful Strategy during a Crisis is an operating pivot for the efficient functioning of Organisations. Strategic Planning and addressing the Economic Crisis are closely related to the modern changing entrepreneurial and organisational environment. Wilson and Eilertsen (2010) demonstrated the relationship between Strategic Planning and the successful address of the crisis, by reducing costs and increasing income, namely by increasing the efficiency of organisations. They highlighted the exploitation of the opportunities presented during the crisis (introduction of new products, expansion to new markets, changes in pricing, investment in new productions, capacity or labour, increased marketing budget) especially for small enterprises. They also highlighted avoidance of threats that appeared during the crisis (reduction of operational costs, avoidance of new recruitments, reduction of surplus staff, reduction of training and development costs, postponment of major projects), mainly for large enterprises. They highlighted three key elements for the success of Strategic Planning in a crisis. Structure (the Organisation possesses a structured procedure of strategic planning with great leadership participation), embrace (the Organisation uses strategic planning in order to 
actually formulate the future and distribute resources and dependence (efficiency and importance of the process of strategic planning during an economic crisis).

The best strategy for the strategic management during a crisis is the exploitation of presented opportunities, investment in innovation and marketing and implemention of an aggressive strategic planning (Afthonidis \& Tsiotras, 2014).

Joyce (2015) studied the effect of Strategic Planning on Public Administration, especially under the influence of an Economic Crisis and the reforms that it brings upon Government and Administrative procedures. Using the example of the Economic Crisis that struck Turkey in 2001, he analysed the procedure of the introduction of Strategic Management in the operation of Public Administration at Central and Regional Level. He claims that based on Strategic Plans implemented based on Strategic Management, especially the alignment of Strategic Management of the Regions and Regional Institutions with that of the Central Government, it is possible to increase efficiency and therefore to provide an opportunity in order to exit the economic crisis. The new Strategic Plans guided by the reforms were incorporated into the existing framework of the National Strategic Plans and Strategies. Strategic Objectives and measurable targets, Performance Measurement with designated indicators lead to increased Efficiency of Services and Public Sector Organisations.

Public Policy is applied during periods of economic crises, with a view to eliminate the disfunctions caused by the crises and to implement reform changes which aim to boost the operation of societies in a new, effective and more efficient mode. Stucler et al. conducted a study on the effect of the economic crisis on public health and the policies used to address it. Starting from the basis that some studies show the negative impact of the economic crisis on the population's health through increased suicides and ischemic episodes, while other studies support the view that these are offset by a reduction in work-related accidents, this study, which was conducted in 26 European Union countries from 1970-2007, examines health indicators in relation to economic indicators such as GDP and rising unemployment. The study confirms the importance of policies in addressing the negative impact of the economic crisis on public health through the design and implementation of programmes aiming to retain work posts and reintroduce workers to their posts so as to limit the negative effects of the phenomenon (Stucler et al. 2009: 315.320 to 321).

Merton (1969) argues that public policies, include unintentional consequences apart from intentional consequences which may cause negative effects. Such a result could be a reduction in efficiency. This approach, on which the movement of Fatalism in Public Policy is based, regards the public 
as a chaotic system in which the chaos in organisations and denial of cooperation by civilians deterministically generates negative effects on attempted changes.

Strategic Management is used in the Economic Crisis as a way to address crises, recovery and introduction into a new era of sound and secure organisational and entrepreneurial operation. This can be achieved in the light of the effect of Strategic Management through a change in the measurable efficiency of organisations and enterprises.

The application of Strategic Management is closely related to the achievement of the Efficiency of Organisations. Campen (1986) analysed one of the most prevalent techniques for the study of the efficiency, benefitcost analysis and econometric predictions of Organisations which are used by policy makers for the creation of policies and decision making in the field of policy analysis. In this study, although the role of the BCA is emphasised for its conservative as well as its liberal view of policy analysis, the intentional or through ignorance abuse and distortion of these techniques is demonstrated. The defective results can influence policy design. The techniques must evolve following new data so that their results are beneficial for policy planning and analysis. Against the importance of the impact of effective measures in the shaping of public policy, Bromley (1990) argues that the criteria of economic efficiency and the optimisation criterion according to Pareto, have not been proven as consistent and integrated with the economic theory and neither do these measures comply with what policy makers analysts seek from economists during the formulation of an effective policy. However, efficiency measures are important parts of the economic theory, especially of the cost-benefit analysis and are used in the analysis of public policy. While economic efficiency has no claim to objectivity, a political scientist can be an objective analyst of the selection of policy. Elimination of the efficiency rule allows the economist to focus the assessment and analysis on aspects of policy analysis options that are more significant to decision-makers (Bromley, 1990: 86, 91-94)

Strategic Management is oriented towards increasing the efficiency of organisations and enterprises, i.e. increasing inflows and reducing outflows. Addressing the threats brought about by the Economic Crisis for Organisations can be realised and, at the same time, the Organisations can take advantage of opportunities arising during the Crisis, survive and develop a more efficient operation. Efficiency Measurement Techniques can be used as part of Strategic Management in order to identify areas in need of improvement regarding entrepreneurial units. Strategic Management includes Information Systems, through the Design and Development of which Organisations can be assisted in addressing the Economic Crisis. 


\section{Strategic Management of Information Systems and Economic Crisis}

Modern organisations face Information Systems as a development tool, especially in the case of an economic crisis, in order to assist the Organisation to emerge from the crisis. Modern Information Systems are subject to the Organisation's Strategic Management in order to help increase its efficiency. The Strategic Management of Information Systems is an integral part of an organisation's modern management strategies, and especially in the case of the Economic Crisis, it ensures a competitive advantage through the alignment of entrepreneurial and IT strategy, increasing efficiency, mainly through the reduction of costs and the exploitation of opportunities and avoidance of threats and finally, the Organisation's or company's unscathed exit from the Crisis leading it into a stronger competitive position than before.

The modern vision of Information Systems focuses on Strategic Information Systems Planning (SISP) which connect the Administrative and Informational function of Organisations and Enterprises. Lederer and Sethi (1988) defined Strategic Information Systems Planning (SISP) as the portfolio identification process of computer-based applications that will help an organisation in the execution of its business plans and thus the achievement of its business objectives (Lederer and Sethi, 1988), (Newkirk \& Lederer, 2007), (Fergerson, 2012). Hevner, Bernt, and Studnicki (2000) state that "SISP is the alignment of an organisation's business strategy with efficient information-based computing systems in order to achieve critical business objectives" (Hevner, Bernt, and Studnicki 2000: 1). Doherty et al. (1999) provide a composite definition from different sources for the SISP as "the identification process of a portfolio of computer-based application which are to be implemented, highly aligned with corporate strategy and with the ability to create an edge over competitors" (Doherty et al. 1999: 265).

Prior to the application of the SISP, the design of the technology of information resources was simply referred to as Information Systems Planning (ISP) (Teo \& King, 1996).

The development of SISP methodologies enabled their development towards integrated management of Information Systems in Organisations and Enterprises. Somendra, Pant and Cheng, Hsu (1995) distinguish SISP methodologies into alignment methodologies (which focus on business objectives by aligning business strategy with IS and adaptation of IS to business processes), and impact methodologies (which aim at competitive advantage through the search for new capabilities - opportunities). Strategic alignment is defined as the inherently dynamic implementation between external and internal entrepreneurial sectors, such as product / market, 
strategy, administrative structures, business processes and IT, Ciborra, C., (1998).

The methodologies which have been developed to align Business Strategy with Information Systems are: Business Systems Planning (BSP) which focuses on business processes arising from the organisation's mission, objectives and targets (IBM, 1982), (Zachman, JA, 1982). Strategic Systems Planning or PROplanner, developed by Robert Holland, and which differs in the automated handling of the data collected during SISP design (Pand \& Hsu, 1995). Informational Engineering (IE) developed by Martin as a structured IT development process with Engineering data (Martin, 1982). Finally, Method / 1 was developed as a comprehensive design process differentiated from other methods in its information design, for designing information systems and installing them in the field of application (Lederer \& Sethi, 1988).

Reich, BH \& Benbasat, I. (2000) studied the factors affecting the alignment between business and IT objectives and strategy and resulted in four: knowledge sharing (joint training programmes) between executive IS staff and business processes, successful IT implementation, communication between IS staff and business processes and linking to business and IT planning processes. Alignment ultimately depends on two factors: the degree of mutual understanding of the current objectives (short-term alignment of the two systems) and the proportion of the vision of IS staff and business processes (long-term alignment of the two systems).

Regarding impact methodologies, Porter (1984) analysed the fundamental importance of IS in relation to the company's value chain, creating the value chain analysis, while Rockard (1979) analysed the introduction of information technologies in the early stages to provide a realistic assessment of the contribution of Information Systems to the organisation developing the method.

Pant \& Hsu (1999) studied the SISP methodologies and developed an integrated framework for the development and design of information systems. Their comparative evaluation for SISP methodologies is shown in Figure 3.

Brumek \& Vrcek (2002) grouped and used the methods and techniques for the strategic planning of information systems. They developed a comprehensive methodology for the efficient development and strategic management of information systems. The summary of the methods for the strategic planning of information systems is shown in Table 1.

The SISP are strongly connected to the achievement of efficiency through the alignment of IT and administrative strategies. King (1978) developed the effect of organisational strategies on IS strategies. Segars, AH, Grover, V. and Teng, JTC (1998) expanded the theoretical model of SISP 
success and strategy with a series of procedures oriented to the human factor, expansion of the solution search, increasing rules and procedures that guide action, creativity or control application, increase of participation in implementing the strategy and growth of programming cycles. Segars, $\mathrm{AH}$, Grover, V. (1998) analysed the relationship of the Strategic Information System Planning and the Strategy for the success of the enterprise and developed a comprehensive model for the measurement of the success of the implementation of the SISP. They felt that the alignment of business strategy with information systems was very important.

Earl (1993) extended the SISP's application not only to IS managers but also to general managers and line managers. Under this approach he distinguished five different SISP methodologies: Business-Led, MethodDriven, Administrative, Technological and Organisational, each with

\begin{tabular}{|c|c|c|c|c|}
\hline Methodology & Focus & Salient Feature & Strengths & Weaknesses \\
\hline $\begin{array}{l}\text { Value Chain } \\
\text { Analysis }\end{array}$ & Impast & $\begin{array}{l}\text { - A form of business } \\
\text { activity analysis } \\
\text { - Helps in devising } \\
\text { information systems } \\
\text { which increase profit } \\
\text { - Concentrates on value- } \\
\text { adding business activities }\end{array}$ & $\begin{array}{l}\text { - Concentrates on direct } \\
\text { value adding processes. } \\
\text { - Is independent of } \\
\text { organizational strueture }\end{array}$ & $\begin{array}{l}\text { - Doesn't address issues } \\
\text { of systems development } \\
\text { and implementation. } \\
\text { - Doesn't define a data } \\
\text { structure. } \\
\text {-Diffieult to apply to } \\
\text { non-manufaeturing firms. }\end{array}$ \\
\hline $\begin{array}{l}\text { Critical } \\
\text { Success } \\
\text { Factors }\end{array}$ & $\begin{array}{l}\text { Impact } \\
\text { as well as } \\
\text { alignment }\end{array}$ & $\begin{array}{l}\text { - Used for identifying } \\
\text { key information needs } \\
\text { of an organization and } \\
\text { its managers. }\end{array}$ & $\begin{array}{l}\text { - Focus on key } \\
\text { information requirements }\end{array}$ & $\begin{array}{l}\text { - Not comprehensive } \\
\text { - Internally focused and } \\
\text { analytical, not ereative. } \\
\text { - Ignores value adding } \\
\text { aspects of Information } \\
\text { Systems. }\end{array}$ \\
\hline $\begin{array}{l}\text { Business } \\
\text { Systems } \\
\text { Planning } \\
\text { (BSP) } \\
\text { (From IBM) }\end{array}$ & Alignment & $\begin{array}{l}\text { - Combines top down } \\
\text { planning with bottom up } \\
\text { implementation. } \\
\text { - Focuses on business } \\
\text { processes. } \\
\text { - Data needs and data } \\
\text { classes are derived from } \\
\text { business processes. }\end{array}$ & $\begin{array}{l}\text { - An integrated method } \\
\text { which combines top down } \\
\text { analysis with bottom-up } \\
\text { implementation. } \\
\text { - IBM being the vendor, } \\
\text { it is better known to the } \\
\text { top management. }\end{array}$ & $\begin{array}{l}\text { - Detailed, time consuming } \\
\text { and eostly. } \\
\text { - Does not incorporate a } \\
\text { software design methodology. } \\
\text { - Requires a high degree } \\
\text { of IT experience within } \\
\text { the planning team. }\end{array}$ \\
\hline $\begin{array}{l}\text { Strategie } \\
\text { Systems } \\
\text { Planing } \\
\text { (PROplanner) }\end{array}$ & Alignment & $\begin{array}{l}\text { A business functional } \\
\text { model is defined by } \\
\text { analyzing major function- } \\
\text { al areas of a business. } \\
\text { - Data arehitecture is } \\
\text { derived from the business } \\
\text { funetion model. } \\
\text { - The above arehitecture } \\
\text { is used to identify new } \\
\text { systems and their } \\
\text { implementation schedules. }\end{array}$ & $\begin{array}{l}\text { - An integrated method } \\
\text { which combines top } \\
\text { bottom-up implementation. }\end{array}$ & $\begin{array}{l}\text { - Detailed, time consuming } \\
\text { and costly. } \\
\text { - Requires a high degree of } \\
\text { IT experience within the } \\
\text { planning team. }\end{array}$ \\
\hline $\begin{array}{l}\text { Information } \\
\text { Engineering } \\
\text { (From James } \\
\text { Martin) }\end{array}$ & Alignment & $\begin{array}{l}\text { - Provides techniques for } \\
\text { building enterprise, data, } \\
\text { and process models. } \\
\text { - These models are } \\
\text { combined to form a } \\
\text { comprehensive know- } \\
\text { ledge base which is used } \\
\text { to create and maintain } \\
\text { information systems. }\end{array}$ & $\begin{array}{l}\text { - A comprehensive } \\
\text { methodology } \\
\text { - Provides automated } \\
\text { tools to link output to } \\
\text { subsequent systems } \\
\text { development efforts. }\end{array}$ & $\begin{array}{l}\text { - Extensive user involvement } \\
\text { - Lengthy } \\
\text { - Difficulty in finding a } \\
\text { team leader } \\
\text { - Difficulty in securing top } \\
\text { management support. }\end{array}$ \\
\hline $\begin{array}{l}\text { Method/1 } \\
\text { (From Anderson } \\
\text { Consulting) }\end{array}$ & Alignment & $\begin{array}{l}\text { - A layered approach } \\
\text { - Top layer is methodology, } \\
\text { middle layer is techniques } \\
\text { supporting methodology } \\
\text { and the bottom layer has } \\
\text { tools supporting techniques. } \\
\text { - Techniques supported: } \\
\text { DFD, Matrix Analysis, } \\
\text { Functional Decomposition, } \\
\text { Focus Groups and Delphi } \\
\text { studies. } \\
\text { - Supported by CASE tool } \\
\text { FOUNDATION. }\end{array}$ & $\begin{array}{l}\text { - Comprehensive } \\
\text { - Provides automated support }\end{array}$ & $\begin{array}{l}\text { - Expensive } \\
\text { - Too detailed } \\
\text { - Time consuming }\end{array}$ \\
\hline
\end{tabular}

Table 1: Comparative evaluation of SISP methodologies (based on Pant \& Hsu, 1999) 
different characteristics and success Bergeron, Raymond, and Rivard (2004) (p. 1003). Fergeson (2012) developed the SISP in connection with an enterprise's SM and analysed the basic methodologies for the study of this relationship. Pearlson, K. \& Saunders, K. (2013) studied the effect of efficiency in the design of IS. Table 1 presents the research studies on the SISP and the relationship to the efficiency of organisations and other measurements.

Wilkin C. \& Cerpa N. (2012) claim that the strategic management of information technology (IT) is seen as a critical component of entrepreneurial efficiency. They investigated the practice and effectiveness of the Strategic Information System Planning (SISP) in conjunction with the Strategic Management of organisations in 29 Australian institutions. They also developed a theoretical procedure for the examination of the results using six identified dimensions for a structured approach for the review of SISP.

Pearlson and Saunders (2013) developed a strategy for information systems, based on the idea of the triangle with Business Strategy, Organisational Strategy and Information Strategy as cornerstones. They used Pearson's overall strategy model for the achievement of a comparative advantage through cost leadership, differentiation and focus on implementing the information systems which state that the IS strategy is selected based on understanding which strategy is applicable to the enterprise. In the context of D 'Aveni's competition, 7s evaluation is required to select the organisation's actions, the IS strategy must be in correspondence with $7 \mathrm{~s}$ results in order to achieve the change. The strategic use of information resources and the strategic alignment of information systems and organisational strategy is believed to be of great importance.

Haque, Hossin \& Khan (2016) highlighted the importance of SISP in the success of the IS and the importance of aligning the IS strategy with the business strategy in Health units of developing economies which are plagued by financial difficulties. They highlighted a dual approach for the implementation of the SISP in health units in order to achieve optimal results for the IS success. The SISP relationship with efficiency, Strategic Linking, Competitive Advantage and Economic Crisis is shown on Table 2.

SISP and Crisis. Ezzamel and Bourn (1990) studied the role of IS in organisations which were faced with financial crises and highlighted the differentiated way in which the IS was used depending on the phase of the crisis in relation to the degree of uncertainty of the organisational objectives and the degree of uncertainty of the cause and effect relationship which refers to the organisational actions and the focus on the use of IS in the Political Dimension of the Crisis. Ciborra, C., (1998), during a study on the relationship of Strategic Information Systems and Crisis considers the gap 
between scientific objectivity and daily life, the lack of a "spiritual" dimension in technological development as the cause of a crisis. The crisis is due to the separation between people and science and the consequent forgetting of the subjective origin of science, the role of everyday life in the creation and development of any methodology and, finally, nature's lethe and the importance of the true human in the management of organisations and technologies. The human factor in IS has been neglected. The divergence between modern IS development methodologies and initial practical IS development and IT is a cause of the crisis created in IS. In turn, the current global economic crisis (to which the Greek Economic Crisis is closely connected) is considered as a crisis within Kondratiev cycle during the recession following the boom in Information Technology. The Kondratiev cycles occur about once every 50 years and lead to a major crisis or a world war (Korotayev \& Zinkina \& Bogevolnov, 2011: 1280-1284).

Information Systems of Organisations and enterprises, very often do not provide the necessary information for the timely approach of an economic crisis. The SISP is not oriented towards dealing with an economic crisis. A more typical example is the failure of adequate information of IS regarding risk management in the banking sector, before and during the American Depression. Although these weaknesses in the design of the systems were identified by specific managers, it was not possible to fix them in the face of an economic crisis. The role of Supervisory Authorities in the non-requirement of Organisations that oversee their IS in order to prepare them for the possibility of the emergence of an Economic Crisis is noted (Hopwood, 2001). The SISP and IS should have included Crisis Management in their content, in order to achieve an effective management of an Economic Crisis.

On the other hand, Castells (1999) highlights the negative character of Information Technology and the general orientation of organised entrepreneurial systems in the creation of Economic and Social Crises. Also, Lyytinen and Robby (1999), mention the impact of the economic crisis in an organisation on the strategy and failure of development of an Information System (Lyytinen and Robby, 1999). Methods and Techniques for Strategic Management for Information Systems are shown on table 3 (based on Brumek \& Vrcek, 2002, Porter, 1979). 
Table 2: SISP relationship with efficiency, Strategic Linking, Competitive Advantage and Economic Crisis

\begin{tabular}{|c|c|c|c|c|}
\hline & Efficiency & $\begin{array}{l}\text { Linking Organisational } \\
\text { and IS Strategy }\end{array}$ & $\begin{array}{l}\text { Competitive } \\
\text { Advantage }\end{array}$ & $\begin{array}{l}\text { Economic } \\
\text { Crisis }\end{array}$ \\
\hline King (1978) & $\mathrm{X}$ & $\mathrm{X}$ & & \\
\hline Ezzamel \& Bourn (1999) & & & $\mathrm{X}$ & $\bar{X}$ \\
\hline Earl (1993) & & $\mathrm{X}$ & & \\
\hline Pant \& Hsu (1999) & $\mathrm{X}$ & $\bar{X}$ & & \\
\hline Castells (1999) & $\mathrm{X}$ & & & $\mathrm{X}$ \\
\hline Brumek \& Vrcek (2002) & $\mathrm{X}$ & $\mathrm{X}$ & $\mathrm{X}$ & \\
\hline $\begin{array}{l}\text { Bergeron, Raymond, } \kappa \alpha \imath \\
\text { Rivard (2004) }\end{array}$ & $\mathrm{X}$ & $\mathrm{X}$ & & \\
\hline $\begin{array}{c}\text { Taewoo Y. \& Hongmin Z. } \\
\text { (2007) }\end{array}$ & $\mathrm{X}$ & & $\mathrm{X}$ & $\bar{X}$ \\
\hline Fergerson, B. (2012) & & $\mathrm{X}$ & $\mathrm{X}$ & \\
\hline $\begin{array}{c}\frac{\text { Pearlson, K. \& Saunders, }}{\text { K. (2013) }} \\
\text { Kell }\end{array}$ & $\mathrm{X}$ & & & \\
\hline $\begin{array}{l}\text { Haque, Hossin \& Khan } \\
\text { (2016) }\end{array}$ & & $\mathrm{X}$ & & $\bar{X}$ \\
\hline
\end{tabular}

The SISP is considered in a modern business environment for its effect on Efficiency and its interaction with Strategic Management. Increase of efficiency through the application of strategic management is achieved through implemention of cost saving policies such as reducing inventories and costs (Afthonidis \& Tsiotras, 2014). Bergeron, Raymond, and Rivard (2004) developed the view that alignment strategies and their implementation are vital for an organisation to exploit information technology so as to achieve greater efficiency. Bruner \& Vrcek (2002) developed a methodological step in the framework of SISP methodology for the functional areas of entrepreneurial operation where the new IS can contribute greatly to the improvement of the efficiency of business processes. The impact of IS on an enterprise's overall performance is assessed and in each business process the necessary information is evaluated and determined so that the top managers can define the objectives of the operational functions. The methods and techniques proposed for the analysis of this function are Balanced Scorecard, BCG - matrix, 5F model and value chain model. Balanced Scorecard examines the relationship between Performances of existing BS / Business Processes. BCG - matrix examines the relationship between the IS Development Priorities / Business Strategy, the $5 \mathrm{~F}$ model examines the relationship between the Information for top Managers / Business Strategy and the Value Chain Model examines the relationship between the Primary and Supporting Business Processes / Business Processes. Finally, the performance of new operational systems is evaluated in conjunction with the performance of new IS, through the 
balanced scorecard method in terms of increasing the efficiency of these systems.

Among the IS design methods, the Business Process Reengineerging method prevails, which places great emphasis on reducing the cost and increasing the quality of service. The BRP method aims directly at increasing the efficiency of organisations, also due to the fact that it processes the mechanical concept of efficiency (Hammer, 1990).

Enterprise Administrations equipped with advanced information systems can provide a competitive advantage in monitoring the performance of the Performance of Organisations and Enterprises in the period of an Economic Crisis. By using large funds through the use of Information Systems, Administrations are informed and monitor the enterprises exercising the right of administration. Measuring Performance of Construction Companies during the Depression of Korea during the years 1996-2000 shows the decrease in Efficiency as a result of

\begin{tabular}{|c|c|c|c|c|c|c|c|}
\hline \multirow{3}{*}{$\begin{array}{l}\text { Description: } \\
\text { Method's } \\
\text { Name }\end{array}$} & \multirow{2}{*}{\multicolumn{2}{|c|}{$\begin{array}{c}\text { first group } \\
\text { methods dedicated to specific } \\
\text { problems related to IS } \\
\text { planning } \\
\end{array}$}} & \multicolumn{3}{|c|}{ second group } & \multicolumn{2}{|c|}{ third group } \\
\hline & & & \multicolumn{3}{|c|}{$\begin{array}{l}\text { previously used in business planning and simply } \\
\text { modified for SPIS }\end{array}$} & \multicolumn{2}{|c|}{ Reengineering methods } \\
\hline & $\begin{array}{l}\text { Business } \\
\text { system } \\
\text { planning } \\
\text { (BSP) }\end{array}$ & $\begin{array}{c}\text { Critical } \\
\text { success } \\
\text { factor ( CSF ) }\end{array}$ & 5F method & $\begin{array}{l}\text { SWOT } \\
\text { ANALYSIS }\end{array}$ & BCG & $\begin{array}{l}\text { BPR Business } \\
\text { Process } \\
\text { Reengineering }\end{array}$ & Value Chain_ \\
\hline $\begin{array}{l}\text { Method } \\
\text { description }\end{array}$ & $\begin{array}{c}\text { Analysis and } \\
\text { design of IT } \\
\text { strategy of } \\
\text { organisations }\end{array}$ & $\begin{array}{l}\text { Search of } \\
\text { component } \\
\text { necessary for } \\
\text { the } \\
\text { organisation } \\
\text { or the project } \\
\text { so as to } \\
\text { achieve its } \\
\text { mission }\end{array}$ & $\begin{array}{l}\text { Determining } \\
\text { whether the } \\
\text { new products } \\
\text { or services } \\
\text { are profitable } \\
\text { and } \\
\text { understanding } \\
\text { the } \\
\text { competitive } \\
\text { position of } \\
\text { the business } \\
\text { operation } \\
\end{array}$ & $\begin{array}{c}\text { Strategic } \\
\text { planning tool } \\
\text { for the analysis } \\
\text { of an } \\
\text { enterprise's } \\
\text { internal and } \\
\text { external } \\
\text { environment }\end{array}$ & $\begin{array}{l}\text { Specifies } \\
\text { which } \\
\text { priorities } \\
\text { will be } \\
\text { given to the } \\
\text { portfolio of } \\
\text { the } \\
\text { enterprise }\end{array}$ & $\begin{array}{l}\text { Business } \\
\text { Process } \\
\text { Reengineering } \\
\text { for reducing } \\
\text { costs and } \\
\text { increasing } \\
\text { quality and } \\
\text { service } \\
\text { performance }\end{array}$ & $\begin{array}{l}\text { A set of activities } \\
\text { that a firm } \\
\text { operating in a } \\
\text { specific industry } \\
\text { performs in order } \\
\text { to deliver a } \\
\text { valuable product or } \\
\text { service for } \\
\text { the market }\end{array}$ \\
\hline How it works & $\begin{array}{l}\text { Developing } \\
\text { future } \\
\text { information } \\
\text { technology } \\
\text { for the } \\
\text { enterprise } \\
\text { and } \\
\text { provision of } \\
\text { a framework } \\
\text { for } \\
\text { informational } \\
\text { investments } \\
\end{array}$ & $\begin{array}{l}\text { Finding } \\
\text { elements that } \\
\text { are crucial to } \\
\text { the success of } \\
\text { a strategy }\end{array}$ & $\begin{array}{l}\text { Analysis of } \\
\text { five forces: } \\
\text { supplying } \\
\text { power, } \\
\text { purchasing } \\
\text { power, } \\
\text { competitive } \\
\text { examination, } \\
\text { substitution } \\
\text { threat, threat } \\
\text { of new entry }\end{array}$ & $\begin{array}{l}\text { The strengths } \\
\text { and } \\
\text { weaknesses of } \\
\text { a company and } \\
\text { the } \\
\text { opportunities } \\
\text { and threats that } \\
\text { exist are } \\
\text { studied }\end{array}$ & $\begin{array}{l}\text { The level of } \\
\text { development } \\
\text { and the } \\
\text { degree of } \\
\text { various } \\
\text { products } \\
\text { that markets } \\
\text { share in } \\
\text { their life } \\
\text { cycle are co- } \\
\text { assessed. }\end{array}$ & $\begin{array}{l}\text { The } \\
\text { fragmented } \\
\text { sub-processes } \\
\text { are designed } \\
\text { taking into } \\
\text { account the } \\
\text { strategy and } \\
\text { objectives. }\end{array}$ & $\begin{array}{l}\text { The idea of the } \\
\text { value chain is } \\
\text { based on the } \\
\text { process view of } \\
\text { organisations, the } \\
\text { idea of seeing a } \\
\text { manufacturing (or } \\
\text { service) } \\
\text { organisation as a } \\
\text { system, made up of } \\
\text { subsystems each } \\
\text { with inputs. }\end{array}$ \\
\hline Disadvantages & $\begin{array}{l}\text { Specialised } \\
\text { personnel } \\
\text { required }\end{array}$ & $\begin{array}{l}\text { No } \\
\text { quantification } \\
\text { of } \\
\text { performance } \\
\text { indicators }\end{array}$ & $\begin{array}{l}\text { Use of quality } \\
\text { measures } \\
\text { only }\end{array}$ & $\begin{array}{c}\text { Not a } \\
\text { comprehensive } \\
\text { study of a } \\
\text { subject matter } \\
\text { but a } \\
\text { complementary } \\
\text { means of initial } \\
\text { examination } \\
\end{array}$ & $\begin{array}{l}\text { The high } \\
\text { market share } \\
\text { and market } \\
\text { growth are } \\
\text { not the only } \\
\text { success } \\
\text { factors. }\end{array}$ & $\begin{array}{l}\text { Accused of } \\
\text { rebirth of } \\
\text { Taylorism } \\
\text { under a } \\
\text { different } \\
\text { label. }\end{array}$ & $\begin{array}{l}\text { Difference } \\
\text { between cost and } \\
\text { the value chain }\end{array}$ \\
\hline
\end{tabular}

Table 3 : Methods and Techniques for Strategic Management for Information Systems (based on Brumek \& Vrcek, 2002, Porter, 1979). 
insufficient information Systems for Monitoring Performance (Taewoo \& Hongmin 2007).

We can introduce an integrated framework for strategic planning of information systems in conditions of economic crisis combining and enriching the studies on strategic management and efficiency of organisations during an economic crisis and strategic management information systems in an economic crisis.

Figure 2 depicts the relationship between Strategic Management, SISP and Crisis Management (Authors, 2016).

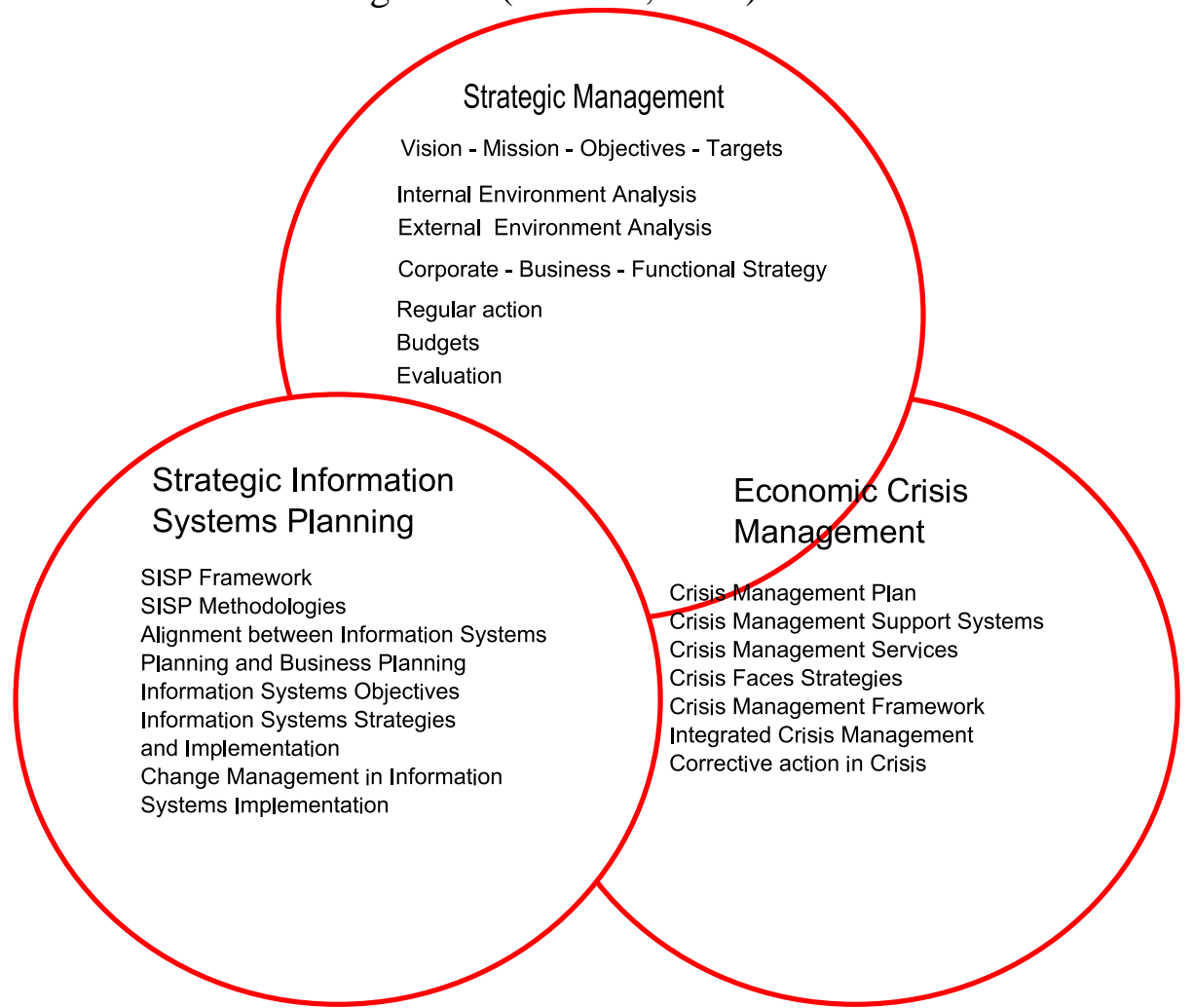

Fig. 2: Relationship of Strategic Management, SISP and Crisis Management (Authors, 2016)

Figure 3 shows the introduction of a strategic planning framework for information systems in conditions of economic crisis. Model.

Figure 4 shows the SISP in Economic Crisis Methodology Meta- 


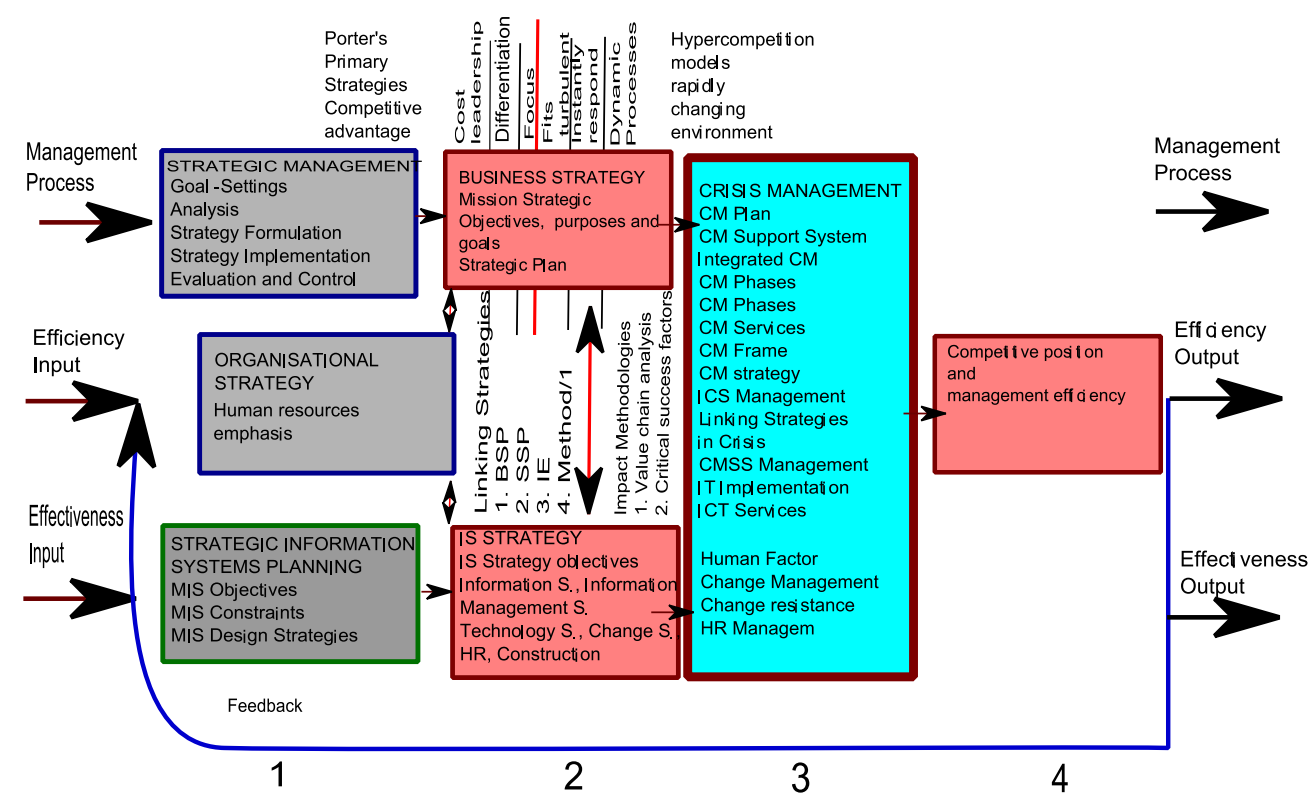

Fig. 3: Introduction of a framework for strategic planning of information systems in conditions of economic crisis (Authors, 2016)

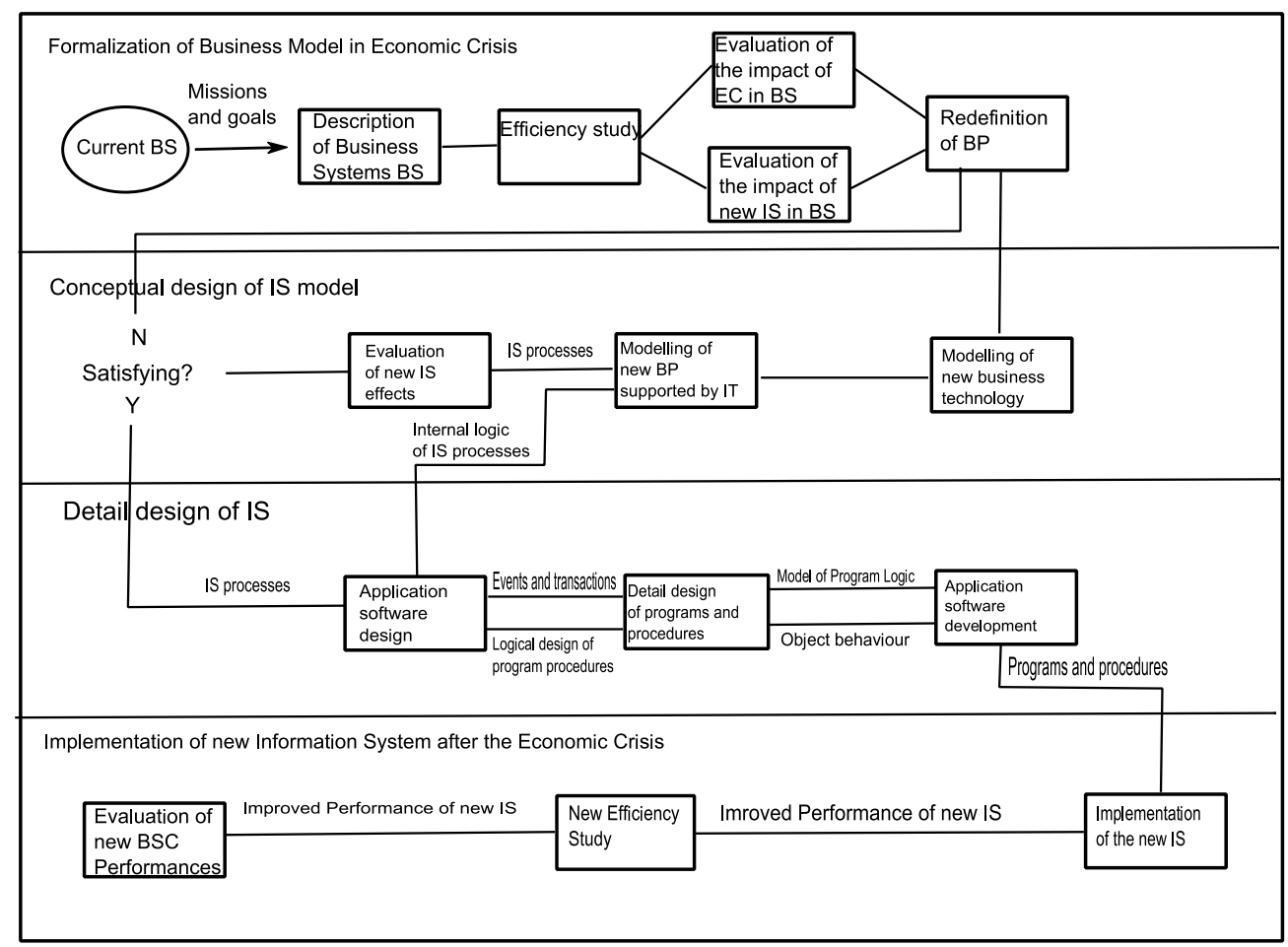

Fig. 4: SISP in Economic Crisis Methodology Meta-Model (Based on Brumek \& Vrcek, 2002 


\section{Conclusion}

The aim of the present study is to establish a framework for the impact of strategic planning on the public sector's information systems during the economic crisis. This framework combines the teachings of the SISP with those of Economic Crisis Management in order to achieve an integrated approach to SISP in the particular circumstances and requirements created by the Economic Crisis. This framework is oriented to the efficient operation of Public Sector Organisations in Economic Crisis conditions. We produced a new metamodel for the SISP methodology in an Economic Crisis which attempts to assess the increase of the measured efficiency after the implementation of the IS changes in relation with the efficiency measured before these changes. The change made regards the joint transformation of business systems and information systems as a result of the reformational IS change that affects the entire business process. This new business process along with the new business and information systems leads to a change in the efficiency of the organisations under the influence of the reform which is caused by the economic crisis. In order to carry out the production of the new framework, the survey has been designed for the literary review of the strategic planning of information systems and was enriched through the review of the effect the economic crisis had on it. We approached the general concepts of Strategic Management compared to the more specific ones of Strategic Planning of Information Systems. We researched the relationship between strategy and crisis and the relationship between efficiency and strategic management in an economic crisis. Based on the results of the survey for the strategic planning of public sector information systems, we enriched the study with specific crisis management and created a new design framework, extracting useful conclusions on the integrated management of public sector information systems during a crisis. The integrated management of public sector information systems in times of crisis, taking into account the lessons learnt regarding crisis management through strategic planning of information systems in crisis conditions, increases the efficiency of Administrative Organisations in Economic Crisis conditions, and ensures the success of the reforms carried out by the Administration so as to Redesign processes and information systems, aiming to increase efficiency. The introduction of the new integrated strategic planning framework for information systems in conditions of economic crisis, combining and enriching the studies on strategic management and efficiency of organisations in an economic crisis and the strategic management of information systems during an economic crisis, contribute to tackling the crisis, incorporating crisis management in the strategic planning of information systems, leading to the replacement of Operational Systems through Styling Operational models in Economic Crisis, the design of 
information systems, the detailed design of the Information System and the implementation of the Information System after the Economic Crisis. The study is limited by the introduction of the economic crisis and cannot be generalised as such in a period of normal operation of the organisations. This original research leaves room for further study cases in the future and for completion of the strategic planning studies of public sector information systems during an economic crisis.

\section{Acknowledgment}

The authors wish to express their gratitude to Mrs Maria-Frederica Gregory, Dip Trans IoL.

\section{References:}

Ansoff, I. (1996). Strategic Management. Classic Edition (p. 272). Palgrave - McMillan.

Afthonidis, E. \&Tsiotras, G. (2014). Strategies for business excellence under an economic crisis, The TQM Journal, Vol. 26 Iss 6, 610 - 624.

Bergeron, F., Raymond, L., \& Rivard, S. (2004). Ideal patterns of strategic alignment and business performance. Information \& Management, 41(8), 1003-1020.

Bracker, J. (1980). The historical development of the strategic management concept. Academy of Management Review, 5(2), 219-224.

Bernanke, B. (2010). Causes of the Recent Financial and Economic Crisis Before the Financial Crisis Inquiry Commission, Board of Governors of the Federal Reserve System, Washington, D.C. : 15-16.

Bromley, D. (1990). The Ideology of Efficiency: Searching for a Theory of Policy Analysis, Journal of Environmental Economics and Management, 19, 86-107.

Brumek, J. \& Vrcek, N. (2002). Strategic Planning of Information Systems: A survey of Methodology, Journal of Computing and Information Technology (3), 227-231.

Campen, J. (1986). Benefit, Cost and Beyond: The Political Economy of Benefit Cost Analysis (pp. 1-256). Longman Higher Education, Cambridge.

Castels, M. (1999). Information Technology, Globalization, and Social Development, United Nations Research Institute for Social Development, 115.

Ciborra, C. (1998). Viewpoint Crisis and foundations: an inquiry into the nature and limits of models and methods in the information systems discipline, Journal of Strategic Information Systems 7, 5-16.

David, F. R. (2009). Strategic management : Concepts and cases (12th ed.). Pearson Prentice Hall. 
Doherty, N., Marples, C., \& Suhaimi, A. (1999). The relative success of alternative approaches to strategic information systems planning: An empirical analysis. The Journal of Strategic Information Systems, 8(3), 263283.

Dorfman, R. (1976). Forty years of cost-benefit analysis, Harvard Institute of Economic Research, Cambridge, MA, Discussion Paper No. 498.

Earl, M. J. (1993). Experiences in strategic information systems planning. MIS Quarterly, 17(1),

$1-24$.

Eldeman, M, (1964). Politics as Symbolic Action, Urbana III: University of Illinois Press.

Ezzamel, M. \& Bourn, M. (1990). The roles of accounting information systems in an organization experiencing financial crisis, Accountings Organization and Society, vol. 15, no 5, 399-424.

Fergerson, B. (2012). Key Stages of Strategic Information System Planning (SISP) Methods and Alignment to Strategic Management Planning Concepts, University of Oregon Applied Information Management Program, 1-115.

Joyce, P. (2015). Strategic Management in the Public Sector , Routledge, Taylor And Francis Group, Oxon,102-112.

Hammer, M. (1990). Reengineering Work: Don't Automate, Obliterate, Harvard Business Review.

Hevner, A. R., Bernt, D. J., Studnicki, J. (2000). Strategic information systems planning with box structures. System Sciences, 2000. Proceedings of the 33rd Annual Hawaii International Conference on, 1-11.

Hunger D., Wheelen, T. (2000). Strategic Management, Prentice Hall, 1-358. Hogwood, B., Gunn, L., (1984). Policy Analysis for the Real World, Oxford University Press, Oxford.

Hoque, M. R., Hossin, M. E., \& Khan, W. (2016). Strategic Information Systems Planning (SISP) Practices In Health Care Sectors Of Bangladesh.European Scientific Journal, 12(6).

IBM (1982). Business Systems Planning: Information Systems Planning Guide, 3rd edition, White Plains, New York, IBM Corporation.

Korotayev, A., Zinkina, J., Bogenolnov, J. (2011). Kontratieff waves in global invention activities (1900-2008), Technological forecasting and social change 78, Elsevier, 1280-1284.

King, W. (1978). Strategic Planning for Management Information Systems, MIS Quarterly, 27-37.

Lederer A., Sethi, V., (1988). The implementation of strategic information systems planning methodologies, MIS Quarterly, 12, 445-461.

Lyytynen, K., Robbey, D., (1999). 'Learning failure in Information Systems development', Info Systems J 9, 85-101.

Martin, J. (1982). Strategic Data Planning Method, Prentice Hall, 1982. 
Rockart, J.F., (1979). Chief Executives Define Their Own Information Needs, Harvard Business Review.

Segars, A. H., Grover, V. (1998). Strategic Information Systems Planning Success: An Investigation of the Construct and Its Measurement, MIS Quarterly (22:2), 139-164.

Segars, A.H., Grover, V., Teng, J.T.C. (1998). Strategic information systems planning: planning system dimensions, internal coalignment, and implications for planning effectiveness, Decision Sciences, Vol 29 No 2, 303345.

Stuckler, D., Basu, S., Suhrcke, M., Coutts, A., McKee, M. (2009). The public health effect of economic crises and alternative policy responses in Europe: an empirical analysis. Lancet, 374, 315-323.

Lowi, T.J. (1964). American Business, Public Policy, Case Studies and Political Theory, World Politics, 16, 677-693.

Merton, R., K. (1968). Social Theory and Social Structure, New York, Free Press, 423.

Newkirk, H. E., \& Lederer, A. L. (2007). The effectiveness of strategic information systems planning for technical resources, personnel resources, and data security in environments of heterogeneity and hostility, Journal of Computer Information Systems, 34.

Osborne, D. \& Gaebler, T. (1992). Reinventing Government: How the Entrepreneurial Spirit Is Transforming the Public Sector. Addison-Wesley Publ. Co.

Pant S. \& Hsu C. (1995). Strategic Information Systems Planning: A Review Information Resources Management Association International Conference, May 21-24, Atlanta, Georgia.

Pant, S. \& Hsu, C. (1999). An Integrated Framework for Strategic Information Systems Planning and Development, Information Resources Management Journal, vol. 12, no. 1, 15-25.

Porter, M., (1979). How Competitive Forces Shape Strategy, Harvard Business Review.

Porter, M.E., (1984). Competitive Advantage, Free Press.

Pearlson, K., Saunders, K. (2013). Strategic Management of Information Systems, 5th Edition International Student Version, 416

Reich, B. H., Benbasat, I. (2000). Factors that Influence the Social Dimension of Alignment Between Business and Information Technology Objectives, MIS Quarterly, 81-113.

Somendra, P., Cheng, H. (1995). “Strategic Information Systems Planning: A Review”, Information Resources Management Association Conference, Atlanta, Georgia. 
Taewoo Y., Hongmin Z. (2007). The economic crisis and efficiency change: evidence from the Korean construction industry, Applied Economics, 39:14, 1833-1842

Teo, T. S. H., King, W. R. (1996). Assessing the impact of integrating business planning and IS planning. Information \& Management, 30(6) : 309. Wheelen, T. \& Hunger, D. (2012). Strategic Management and Business Policy. Toward Global Sustainability. Pearson, New York, 1-35.12.

Wilkin C., Cerpa N. (2012). Strategic Information Systems Planning: An Empirical Evaluation of Its Dimensions, Journal of Technology Management \& Innovation vol.7 no.2, Santiago.

Wilson J., Eilertsen S., (2010). How did strategic planning help during the economic crisis?, Strategy \& Leadership, Vol. 38 Iss 2, 5 - 14.

Zachman, J.A. (1982). Business Systems Planning and Business Information Control Study: a comparison, IBM Systems Journal, 21. 